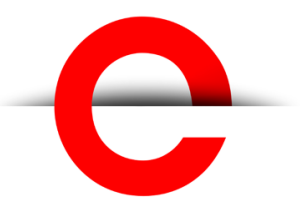

U T S

e PRES S
Gateways:

International Journal

of Community

Research and

Engagement

Vol. 12, No. 1

February 2019

(c) 2019 by the author(s). This is an Open Access article distributed under the terms of the Creative Commons Attribution 4.0 International (CC BY 4.0) License (https:// creativecommons.org/licenses/ by/4.0/), allowing third parties to copy and redistribute the material in any medium or format and to remix, transform, and build upon the material for any purpose, even commercially, provided the original work is properly cited and states its license.

Citation: Kitawi, A. 2019 Improving transition rates of students in informal settlements into higher education: An analysis of the Macheo Mentoring Programme, Gateways: International Journal of Community Research and Engagement, Article ID 6150. https://doi.org/10.5130/ijcre. v12i1.6150

ISSN 1836-3393 | Published by UTS ePRESS | http://ijcre. epress.lib.uts.edu.au
RESEARCH ARTICLE (PEER-REVIEWED)

\section{Improving transition rates of students in informal settlements into higher education: An analysis of the Macheo Mentoring Programme}

\author{
Alfred Kitawi \\ Centre for Research in Education, Strathmore University, Nairobi, Kenya, P.O. Box 59857-00200; \\ akitawidstrathmore.edu
}

DOI: https://doi.org/10.5130/ijcre.v12i1.6150

Article history: Received 04/09/2017; Revised 08/09/2018; Accepted 02/12/2018;

Published 19/02/2019

\begin{abstract}
This research presents a viable way to encourage students in informal settlements to transit from high schools to tertiary institutions by focusing on the case of the Macheo Mentoring Programme of Strathmore University, Nairobi, Kenya. The aim was to investigate how the Macheo Mentoring Programme contributed to the academic success of final year students, with a focus on subjects and overall performance. Though Macheo has other aims, such as provision of life skills, the research examined mainly academic performance, providing insight to how universities can structure their own high-school mentoring programs, the processes that need to be in place and possible challenges they may experience. The research contributes to the literature on the university's role in encouraging student participation. Information was gathered from a cross-sectional survey questionnaire of 72 parents and 76 students. Other qualitative information was gathered to provide insight to what could have contributed to students' success and further augmented quantitative responses. The conclusion was that there is a link between mentorship and students' success. Though this finding is similar to that of most studies undertaken in the Global North, this study aims to combat the dearth of such research in the Global South. The research indicates implicit connections between the university and community, which can be leveraged if they work together as partners.
\end{abstract}

\section{Keywords}

university-community service, mentoring, transition to tertiary institutions, informal settlements
1 
U T S

e PRES S
Africa has experienced an upsurge in student numbers in recent years. It is estimated that between 1990 and 2012, the number of students in primary schools almost doubled. Moreover, compared with other countries, the most positive gains in secondary education occurred in Africa (AAI 2016). Despite these impressive gains, no African country has achieved universal primary education even though Africa allocated on average 5 per cent of its GDP to public expenditure on education. In addition, students from the African continent experience a number of academic challenges, involving both quantity and quality issues. In terms of quantity, three critical issues are access, availability and affordability. 'Some parents are unable to maintain their children in school and maintain their attendance, regardless of free primary education. HIV and Aids have killed many parents and orphaned many children. As a result many children end up working, leading to low enrolments and irregular school attendance' (E1 Bouhali \& Rwiza 2017), while orphaned children have a high rate of absenteeism and truancy. In terms of quality, relevance and effectiveness appear to be constant issues in the education system. In a 2010 Uwezo study of children aged 3 to 16 years in over 2000 schools in Kenya, only 33 per cent of children in class 2 ( 7 years of age) could read a paragraph and 25 per cent of class 5 students (aged 10 years) could not read a class 2 paragraph (Allavida 2012).

Kenya, one of the 54 African countries, and the context for the research, has experienced a number of changes in the education sector that have presented some challenges. In 1985 , the then president, Daniel Arap Moi, introduced a new system of education, the 8-4-4 (eight years of primary education, four years of secondary education and four years of university education). Four years later, as a result of structural adjustment programs, the amount of government financial support was reduced. This meant that funds allocated to different sectors, including education, declined. In 1990, as a result of the Jomtien declaration, many developing countries took on the responsibility of ensuring education for all by adopting a framework for action to meet basic learning needs. Twelve years later, as a result of an election pledge, the new government introduced Free Primary Education (FPE). The aim was to increase access to primary education. This was followed in 2008 by Free Day Secondary Education (FDSE), which aimed at accelerating enrolment and the quality of education (Sava \& Orodho 2014). The outcome of some of these interventions has been increased numbers of student enrolments in primary and secondary education. However, this has created a burden on the limited physical facilities and resources available, poor teaching quality, reduced performance in STEM subjects, creation of non-formal schools, especially in informal settlements, and massive delays in completing either primary or secondary schooling Abuya \& Ngware 2016; Allavida 2012).

In Kenya, informal settlements grow at an average rate of 5 per cent every year. These settlements are also referred to as slums. In Nairobi, Kibera, Korogocho, Kawangware, Viwandani and Mukuru are examples of informal settlements. In Kisumu, such settlements are located in the areas of Bandani, Obunga, Manyatta Arab, Nyawita and Kaloleni. Many people in slums are enmeshed in a poverty trap. Slum dwellers are subjected to horrific socioeconomic conditions, including lack of clean water and sanitation, lack of a clear mechanism for managing solid waste, and dilapidated hospitals and schools) (Mutisya \& Yarime 2011). In terms of schooling, informal schools, also known as low-cost private schools or private schools for the poor (PSP), are mainly run by philanthropic and religious organisations. They charge a very small amount to pay for the few teachers they employ. Low-cost private primary schools are the preferred choice of parents due to the proximity and relatively smaller class sizes (Sais 2016). Overall, however, informal schools are of poor quality with a high teacher to pupil ratio (average of 1:97), teachers are untrained and, in some schools, up to six children share a single 
textbook. These factors contribute to low learning outcomes (Mugo 2012). Some institutions, including universities like Strathmore University in Nairobi, are close to slum areas, in this instance, the Kibera slum. A university may choose to become involved in some of the socioeconomic issues that slums experience

\section{Mentoring embraced as university-based community service}

A university operates in an open environment. It interacts with businesses, family organisations, government, civil and public authorities, non-governmental organisations and various societies. It has a triple mandate: teaching, research and community service. University activities have both direct and indirect effects. In relation to community service, a university can involve itself in community issues in remote communities or communities close to the institution. Community service is a form of civic involvement. In the context of universities, community service helps university students to involve themselves with people from different backgrounds. This enables students to think through and reflect on possible solutions to challenges that these communities experience. This may create in university students transformative learning capabilities when experiencing dilemmas, make them more open to diversity (Williams, Krista \& Claire 2016) and also create socially responsible leaders (Dugan 2006).

Community service is the engagement of students in activities that primarily focus on the service being provided and its benefits to the recipients; it is an experiential form of education. In the case of this research, community service benefits pass to both the communities where service is provided and the university students involved in the activities (Furco 1996). Here, universitybased community service involves identifying high-school students' needs and considering how these needs can be met. The framework response being examined is that of mentorship.

There are many and varied models of mentoring. At its simplest, a mentor is an experienced and trusted adviser. Mentoring also creates possibilities and provides guidance and support to others in a relationship of trust (Cranwell-Ward, Bossons \& Gover 2004). Important and useful models have been developed by Brockbank and McGill (2006) and Keller (2007). Jacobi (1991) and Rhodes (2002) define three types of mentoring: youth mentoring, academic mentoring and workplace mentoring. Youth mentoring is where an adult supports a young person emotionally, psychologically and in personal cognitive growth. Academic mentoring involves a faculty member or a member who is more knowledgeable providing support and guidance to a younger student. Workplace mentoring is where a colleague provides support to another colleague for the purpose of personal and professional growth (Higgins \& Kram 2001). The Macheo Mentoring Programme aligns closely with this type of mentoring model. The academic mentoring approach used in this research involves the individual placement of university students who volunteer to offer mentorship to high-school students, guided by a supervisor (Thomson et al. 2008). The work of Murray (2001) was also influential in the development of the Macheo Mentoring Programme. She examined how to implement the mentoring process comprehensively. The elements in her model include: assess the readiness of the organisation to mentor; identify protégés (i.e. people eligible for mentoring); develop processes, goals and plans for mentoring; match mentors and protégés; orient mentors and protégés; design development plan; negotiate agreement; execute development; facilitate exchange experiences; conclude agreements.

Contextually, there are examples of academic mentoring in Africa, for instance, Matie Community Service and SHAWCO (Students' Health and Welfare Centres Organisation). The Matie Community Service (formerly USKOR) was formed as a non-profit organisation 
U T S

e P R E S S

of Stellenbosch University, South Africa. Matie offers a structured volunteer experience, comprising information sessions and short courses, serving the need of local communities for adult basic education, training and primary health care. The adult basic education program focuses on illiterate and semi-illiterate adults, people with disabilities and out-of-school youth. SHAWCO, which is run by the University of Cape Town (UCT), is a large student volunteer organisation which initiates health and education projects throughout South Africa and also runs primary health-care clinics and education programs. The education projects aim to improve the ability of learners to access education, increase tertiary access to both universities and colleges, and offer additional interventions in extracurricular activities (UCT 2018). In Kenya, no private or public university has a structured mentoring process to support highschool students, especially those in informal settlements, to transit to tertiary institutions. Consequently, data about these students are limited.

In terms of empirical evidence (on university-community services) relating to student support before the 1980s, data on the benefits of community service are sparse. Recent studies on the benefits of community service, however, have included measures of students' self-esteem, efficacy, political behaviours and social attitudes. A similar case to the Macheo Mentoring Programme is the Big Buddies program in America, a peer mentoring-tutoring project that has designed approaches to minimise school attrition and expand undergraduate students' experience of social work. The outcomes from the program were that the Big Buddies improved in self-esteem, students' academic performance also improved, students had better attitudes, and cooperative behaviours were realised. The tutors also appreciated the need to help the less fortunate (Dennison, 2000). Another case comparable to the Macheo Mentoring Programme involved research with adolescent children who displayed delinquent behaviours (Jackson 2002). The children were paired with mentors who organised weekly supervision sessions. The outcomes included improvement in the children's behaviour and in the mentors' knowledge of children's issues. The mentors also had a more focused education goal. Lastly, a study done at the Community Services Office at Moravian College indicated that, through mentoring, college students who attended The Learning Connection (TLC) camps were better able to value children and themselves, while at the same time increasing their academic scores (Schmidt, Marks \& Derrico 2004).

As research in the Global South is limited, the aim of this article is to help address this deficiency. The aim of this research was to find out how Strathmore University's Macheo Mentoring Programme has contributed to the transition of final year high-school students to tertiary institutions by comparing final year scores of mentored students with countrywide scores from 2014 to 2016. Perceptions, gathered from surveys of parents/guardians and students, of what may have contributed to student success are also presented. These insights provide information on crucial programmatic aspects of such mentoring initiatives in universities to assist them to fulfil their community service role. The outcomes contribute to the limited body of knowledge on university-community service contributions in the Global South context.

\section{The case of Strathmore University's Macheo Mentoring Programme}

Strathmore University is a fairly young university situated in Nairobi, Kenya. It was awarded a charter to operate as a fully-fledged university in 2008. The Macheo Mentoring Programme started in 2012 and is just one of the volunteer programs organised and directed by the 
university's Community Service Centre (CSC), an administrative entity of Strathmore University, with its own clear function and structure. Other community outreach programs in which the university is engaged include: educating prisoners (in Langata Prison and Naivasha Maximum Security Prison) to acquire accountancy certification, visits to children's orphanages, constructing classroom blocks in remote areas, tree-planting initiatives, offering education management courses to education managers in remote arid and semi-arid (ASAL) areas, and student work camps. Community outreach activities have been running for more than 20 years (from the time Strathmore was a college and later a university). Community outreach activities rely on the goodwill of student volunteers, who receive no monetary compensation.

Macheo, which means sunrise in Swahili, is an after-school education support program that developed as a consequence of interactions between another of Strathmore University's community outreach programs and the residents of one of the largest slums in Africa, the Kibera slum. During the investigations and interactions with 430 teachers and principals who were attending short courses on education management in 2007, some cited a need to increase completion rates of secondary school students in the slum areas. This implies that the Macheo Mentoring Programme arose from these first interactions as a means to complement and not supplement teachers and principals' efforts in schools. Four schools in the Kibera slum formed the first batch of schools for Macheo intervention. It has to be iterated that, at the beginning, the intervention was not based on previous empirical studies, but on the concerns expressed by teachers and a need to contribute solutions to these concerns. Other schools have joined the Macheo Mentoring Programme over time, again because of interest shown by the principal of a school in a slum area. Consequently, one of the critical ingredients for intervention was support and commitment from the school's leadership. Without this support, Macheo Mentoring Programme directors could not intervene and provide assistance to the school and its students. The primary objective of Macheo was thus to assist in improving the academic performance of students and providing life skills sessions.

To start with, a maximum of four students were chosen from each of Forms 2, 3 and 4 in each school. (Form 1 students were not chosen because it was perceived that they needed time to adapt to a high-school setting since they had just transited from primary school.) The limit was established based on the existing resources of mentors and the physical and other support structures available. The criteria and process of selection are outlined below in detail. The students who were chosen were those who demonstrated academic potential and came from the most challenging backgrounds. Emphasis was also placed on gender balance. After some time, some schools from Kawangware slum were added, having heard from their peers in Kibera of the benefits accruing to students who participated in Macheo. The population of those living in Kibera is the largest at 1020 000, while Kawangware's population is 210000 (Omenya \& Lubaale 2012). From these two populations, approximately 60 per cent, according to current online UNESCO statistics, are of school age, that is between 5 and 24 years (UIS 2018). This implies that there is a very big population of youth surviving in these slums and a need for further interventions.

The academic sessions are conducted during the weekends - classroom sessions vary from two to four hours and individual mentoring sessions are 30 minutes in duration. During the sessions, students can seek clarity on subjects and issues that were not clear during their normal daily classes. The students are given past papers from other well-performing schools. The teachers employed in the Macheo Mentoring Programme are normally from the wellperforming schools and are paid every month. These teachers examine students' knowledge and revision techniques and provide advice on reading and revision techniques. They also 
U T S

e P R E S S

act as role models (Dignitas 2008; Kathuri \&Juma 2007). Macheo Mentoring Programme evaluators cannot examine the quality of learning in schools where these children come from. This is because, legally, no other agent of the government apart from the Teachers' Service Commission (TSC) is allowed to check teaching quality in schools. TSC is also responsible for teachers' registration and human staffing issues. University student mentors of high-school students attend the classroom sessions and provide one-on-one mentoring to students after these sessions.

Some other ways in which Macheo supports students is by providing funds from wellwishers to purchase learning materials and revision kits. This contrasts with other remedial programs in the country, for instance those in Kenya, which are supported by individual parents and communities and whose aim is mainly academic support, as explained in general by Glennerster, Kremer, Mbiti \& Takavarasha (2011). Furthermore, the aforementioned research stresses that benefits of remedial education have been shown at primary school level but not at higher levels. Figure 1 shows the framework for the Macheo Mentoring Programme, which includes elements borrowed from Murray's (2001) comprehensive mentoring framework.

\begin{tabular}{|c|c|}
\hline $\begin{array}{l}\text { Mentorship } \\
\text { Potential student is contacted (screening } \\
\text { of mentees/protégées); mentees attend } \\
\text { information sessions; mentee is invited } \\
\text { for orientation; match is made between } \\
\text { mentor and mentee; student orientation } \\
\text { with primary mentor; mentoring } \\
\text { programme is planned; mentor training } \\
\text { workshops; learning contracts are } \\
\text { negotiated; student works through } \\
\text { programme; mentor coordinates and } \\
\text { guides student; } \\
\text { monitoring/evaluation of outcomes (exit } \\
\text { interviews and committee evaluations) }\end{array}$ & $\begin{array}{l}\text { Students' success } \\
\text { Pass in school and final Kenya } \\
\text { Certificate Secondary Examination } \\
\text { Transition into tertiary level } \\
\text { Possession of life skills (e.g. critical } \\
\text { thinking and social skills) } \\
\text { Creation of a sense of responsibility } \\
\text { Creation of positive attitude } \\
\text { towards learning }\end{array}$ \\
\hline
\end{tabular}

Figure 1 Framework for the Macheo Mentoring Programme

As mentioned earlier, the focus of the outcomes of this research is mainly on passing subject exams and transitioning to tertiary institutions. Examination of life skills, creation of a sense of responsibility and creation of positive attitudes, which are part of the Maccho Mentoring Programme's aims, are not discussed. Nor are the benefits to the university students who come to learn how their service makes a difference to the lives of children in informal settlements. This can be investigated in future research. The main reason that Strathmore University students involve themselves in this and other community service initiatives is to give back to society. Students are not paid for engaging in outreach activities. Macheo supplements the core curriculum provided to university students who are registered to undertake degree and diploma programs by training them on how to mentor students to become leaders. The mentors are given leadership and communication skills sessions to help them communicate and transmit life skills to high-school students. 


\section{THE MACHEO MENTORING PROGRAMME: HOW IT WORKS}

When developing the Macheo approach, CSC examined approaches in place around the world. The most ideal was the Empire State College of the State University of New York (SUNY-ESC) mentoring model, which borrowed heavily from the Murray (2001) model. SUNY-ESC has, since 1971, employed mentoring for academic instruction and advancement (for more on this model see https://www.esc.edu/cmlai/). The University of New York had another similar program to mentor, register and track cancer patients (Murray 2001). Its approach involved community service in the area of health and had different aims from that of Macheo. The key elements of the SUNY-ESC model were used to inform Macheo, which works in the following way. University students approach CSC to volunteer for the Macheo Mentoring Programme. Once students express interest in joining, they are oriented and given short induction courses by the director of Macheo. Potential high-school students are contacted and interviewed. Currently, there are nine schools involved, which include schools within Kibera and Kawangware slums. Typically, invitations are made through the principals of the respective schools to students in Form 2. Macheo involves students from Form 2 to Form 4. Students can range between 14 and 17 years of age, depending on whether the students were enrolled on time or late. The process of induction into the Macheo Mentoring Programme takes place as follows: parents or guardians of students are informed that their son or daughter will be mentored; secondary school students attend information sessions where they are inducted into Macheo (with a keen focus on gender parity: a male university student mentors a male high-school student and likewise for female mentor-mentee pairs); a match is made between the mentor and mentee by the coordinator and director. Thereafter, the mentor agrees with the mentee on frequency of meetings and issues that will be discussed in each meeting. Mentoring sessions concentrate on academic issues and life skills. In terms of academic assistance, the main subjects covered are Mathematics, English, Kiswahili, Biology, Chemistry and Physics. The sessions occur on the first, second and fourth Saturday of each month from January to November, and are held in Strathmore University lecture halls, which are a 30-minute walk from Kibera. Since the Macheo Mentoring Programme started in 2014, at least 250 high-school students have been enrolled and none has dropped out.

Two coordinators and a director have been employed full-time for the Macheo Mentoring Programme. The coordinators deal with daily operational issues and the director focuses on strategic plans and their implementation. The director regularly carries out evaluation of the mentors, mentees and support teachers who offer assistance to the students. The support teachers give guidance to the mentors on the main examinable subjects. The teaching focus in Form 2 and 3 classes during the Macheo sessions is mainly on all the critical areas for which the support teachers feel the students need to have a firm grasp and the Form 4 sessions are focused more on addressing weak areas identified from the assessments. At the end of every year, teacher and student evaluations are carried out. The outcomes of the evaluations inform the focus of Macheo in the following year. The teacher evaluations include areas where teachers think new focus is needed based on class discussions and assessments, the kind of teaching materials they need, and learner needs. Student evaluations are done via questionnaires given to students. From these, teachers evaluate the kind of extra support students need in subject topics, examinations and use of laboratory equipment, and if extra practical sessions in science are required. They also gauge the frequency of contact between mentor and mentee and the depth of mentorship conversations, as well as relations at home and at school and the challenges the students face. Special attention is given to the responses of outgoing Form 4 students. Strathmore support teachers give regular formative 
U T S

e PRES S and summative assessments of high-school students who attend the Macheo Mentoring Programme. The formative assessments are given throughout the school term and take the form of assignments and tests, while summative assessments are given once a term (COP 2013).

Thus far, an explanation has been offered about the structure, development and intentions of the Macheo Mentoring Programme. The article will now explore the aims of the research, whose objectives were:

(1) To find out how Macheo contributed to final year student success in the various subjects, compared with country subject mean scores, and consequent levels of transition from secondary to tertiary education

(2) To examine the possible reasons behind student success in various subjects and thus transition from secondary to tertiary education.

\section{Methodology}

Mixed methods research is an approach to inquiry that employs both quantitative and qualitative aspects (Creswell 2008). It mixes both approaches in the study to give more depth to the data and interpretations. This research used mixed methods because the first research questions were approached quantitatively (focus was on student scores) and the second research question, qualitatively (focus was on perceptions). The research is etic in nature because it used pre-existing definitions and explanations of mentoring, students' success and community service (Punnett et al. 2017). The research evaluated perceptions from students and parents on which aspects of the mentoring process assisted in improving student scores. These responses were captured in a semi-structured questionnaire that had three sections: background factors, mentorship, students' success. The section on background factors examined background influences such as age, gender, the school a student belonged to, whether a student was residing with a parent, number of siblings, if parents/guardians offered financial support for education, a parent's awareness of their child's close friends, if a parent supported their child's attendance in Macheo and if a parent provided emotional and moral support. The mentorship section queried how a student was inducted into the mentorship, if briefing on the objectives of mentoring was given, whether matching of mentor and mentee was performed, if the mentor had changed since becoming involved with Macheo, the type of discussions a student had with his/her mentor, whether mentoring sessions were planned, mentorship satisfaction level, availability of mentor, whether evaluative meetings were held at the end of the year and if a student wanted to continue with Macheo. The students' success section verified if performance in class exceeded average, if performance had improved since being involved with Macheo, whether students were convinced they would pass their final examinations, other skills acquired through Macheo and whether students thought they would transition into tertiary institutions.

Final year Kenya Certificate of Secondary Education (KCSE) examination records were used to compare and contrast changes in performance. A Z-test of mean differences was used to compare performance through time. A Z-test is used when a researcher has randomly selected large samples; the dependent variable is normally distributed and knows the mean of the population and standard deviation (Heiman 2011), which applied in this research. In the case of the data presented in this research, the researcher focused mainly on post-test data, that is, data after intervention, and did not look at responses and performance before the 
intervention (before 2014). The outcomes of this research can be used to build a more robust longitudinal study through time and therefore elaborate on changes, impact and challenges experienced through time.

The parents' questionnaire had similar questions to the students' questionnaire but took a guardian/parent perspective to gauge whether they understood the same issues in the same way as their children. This was important to ensure that many stakeholders' views would be incorporated and solutions suggested would be multi-pronged. Parents are the immediate community, but the perspectives of parents are absent from most of the mentoring literature (Karcher, Claytie \& Powell 2002; Spencer 2010). The questionnaire, as mentioned previously, does not gauge the change in perceptions, but perceptions at a particular point in time (2017). For later research studies, there is an intention to determine whether the perceptions of students in the Macheo Mentoring Programme have changed, though this will be a new population of parents and students. Most of the data in the questionnaire were ordinal in nature and therefore an ordinal test of relation was used. The Chi-square test was used to test the relationships for the second research question.

\section{SCOPE AND DATA ANALYSIS}

The final sample that filled in questionnaires consisted of 76 students and 72 parents. This sample is sufficiently representative of the actual population of 170 students and 170 parents (the sample size is at a margin of error of less than 0.2 , using the $Z$-score at 95 per cent confidence interval and 0.5 standard deviation). The questionnaires were administered by the managers of the Macheo Mentoring Programme in a convenient way, dependent on the availability of students and parents, i.e. those who said they could give responses. The students came from nine different schools in informal settlements. All students were within the age bracket of 16-20 years; 42 were male and 34 female. In the case of parents, 34 were male and 37 female. One person did not indicate gender. Fourteen parents were within the age bracket of 20-30, 26 between 31 and 40,21 within the 41-50 bracket and 10 were above 50. This implies that most parents were in the youth age bracket using the African Youth Charter Standard age bracket of 15-35 (African Union 2006). The analysis was based on a crosssectional survey during the months of April to September 2017, and not a longitudinal survey.

\section{RELIABILITY AND VALIDITY}

Validity was ensured through content validity and face validity (Bordens \& Abbott 2011). Face validity was ensured by asking two experts if the data asked for in the questionnaires corresponded to the themes and research questions. Content validity was assured through the use of the same core aspects of the SUNY-ESC, New York model (Beins \& McCarthy 2012; Burgess 1989). Reliability tests were done using the Cronbach alpha test (Cohen, Manion \& Morrison 2007). The items in the parents and students' questionnaire were similar, with few differences in terms of phrasing and context. The Cronbach alpha value calculated was 0.845 for 34 items, which implies the questionnaires were reliable.

\section{RESEARCH ETHICS}

Research ethics were ensured through anonymity of accounts by not revealing specific information about individuals, such as a person's name and other personal information. The researcher asked for permission from the university and respondents to gather the information. Parents who filled in the questionnaire were informed that their children would fill in a 
U T S

e P R E S S

questionnaire with similar questions to those in their questionnaire. Participants were allowed to answer or not answer certain questions in the questionnaire (Beins \& McCarthy 2012; Burgess 1989). An option was provided in the questionnaire for each question a person was free not to answer. Each parent was asked to fill in a research consent form before their child provided a response and parents were asked to fill in individual consent forms.

\section{Results}

\section{COMPARISON OF FINAL YEAR SUBJECTS' SCORES WITH COUNTRY SUBJECT MEANS AND CONSEQUENT LEVELS OF TRANSITION}

The following tables compare Form 4 KCSE Macheo subject performance and country-wide mean scores over the three years that the Macheo Mentoring Programme has been running. Because each region in the country presents a different subject mean, with the highest means normally reported within urban areas, compiling country means has required some approximation.

Table 1 Comparison of final year scores

Comparison of subject mean scores of final year Macheo students with country performance

\begin{tabular}{|c|c|c|c|c|c|c|c|c|c|c|c|c|}
\hline \multirow[t]{2}{*}{ Year } & \multicolumn{2}{|c|}{ Maths } & \multicolumn{2}{|c|}{ English } & \multicolumn{2}{|c|}{ Kiswahili } & \multicolumn{2}{|c|}{ Chemistry } & \multicolumn{2}{|c|}{ Biology } & \multicolumn{2}{|l|}{ Physics } \\
\hline & M & C & M & C & M & C & M & C & M & C & M & C \\
\hline 2014 & 3 & 1 & 5.68 & 3 & 3.88 & 5 & 2.44 & 2 & 2.81 & 2 & 2.5 & 3 \\
\hline 2015 & 4.65 & 1 & 5.39 & 4 & 5.17 & 5 & 5.41 & 2 & 5.56 & 2 & 5.14 & 4 \\
\hline 2016 & 3.00 & 1 & 3.22 & 4 & 6.91 & 5 & 2.70 & 2 & 2.80 & 2 & 2.00 & 4 \\
\hline 2017 & 5.25 & 1 & 4.32 & 4 & 4.82 & 5 & 3.93 & 2 & 1.92 & 1 & 2.21 & 2 \\
\hline Total & 15.9 & 4 & 18.61 & 15 & 20.78 & 20 & 14.48 & 8 & 13.09 & 7 & 11.85 & 13 \\
\hline Av. & 3.98 & 1 & 4.65 & 3.75 & 5.19 & 5 & 3.62 & 2 & 3.27 & 1.75 & 2.9625 & 3.25 \\
\hline
\end{tabular}

$M=$ Macheo Mentoring Programme performance

$\mathrm{C}=$ Country performance

\begin{tabular}{|l|l|l|l|l|l|l|}
\hline & Mathematics & English & Kiswahili & Chemistry & Biology & Physics \\
\hline Z-test & 0.01408 & 0.21255 & 0.778265 & 0.09722 & 0.14823 & 0.75552 \\
\hline $\begin{array}{l}\text { Country } \\
\text { average } \\
\text { grade score }\end{array}$ & 1 & 3.75 & 5 & 2 & 1.75 & 3.25 \\
\hline
\end{tabular}

In all the five subjects, the average grade score was above the country-wide scores. In 2014, for the first group completing the Macheo Mentoring Programme, two Macheo subjects showed a lower performance than the country-wide mean score: Kiswahili and Physics. In the other three subjects, Mathematics, English and Chemistry, the Macheo students performed better. In terms of subject differences, the main subject which showed a significant difference from country mean scores from 2014 to 2017 was Mathematics with sig $=0.014$. This was because the Macheo average student performance was consistently well above the country average, 
while in the other subjects the scores were close to the country mean performance. Further, there was a relationship between the performance in Mathematics and Biology and Chemistry performance for the three years. If students performed well in Mathematics, for instance in 2015, performance in Biology (5.56) and Chemistry (5.41) was found to be equally high.

When the performance in the different subjects is compared for inter-subject mean performance (that is, mean performance for the various subjects from 2014 to 2017), no significant mean difference was identified. This implies that interventions by the subject teachers were similar over the three years and thus yielded almost similar results. This was to be expected as the same support teachers had been giving assistance to the students since Macheo started.

\section{TRANSITION RATES FOR MENTORED STUDENTS}

The current transition rate (in 2017) of students in the Macheo Mentoring Programme from secondary to university education is 19 per cent, which is above the average country-wide transition rate of 12 per cent (i.e. 70073 out of 610501 had a $\mathrm{C}+$ result and above; $\mathrm{C}$ being the average cut-off grade) (Onsongo 2017). In total, 33 per cent of Macheo students transited to tertiary institutions, including both universities and colleges, in 2017. Table 2 presents the transition rates of Macheo and the whole country and Table 3 compares performance over 2014-2017.

Table 2 Comparison of students transitioning from secondary to tertiary level education

\begin{tabular}{|c|l|l|l|l|}
\hline Year & $\begin{array}{c}\% \text { of students } \\
\text { who can gain } \\
\text { entry into } \\
\text { university from } \\
\text { Macheo }\end{array}$ & $\begin{array}{c}\text { \% of students } \\
\text { who can gain } \\
\text { entry to technical } \\
\text { institutions from } \\
\text { Macheo }\end{array}$ & $\begin{array}{c}\% \text { of students } \\
\text { who can } \\
\text { gain entry to } \\
\text { university at } \\
\text { country level }\end{array}$ & $\begin{array}{c}\% \text { of students } \\
\text { who can gain } \\
\text { entry to technical } \\
\text { institutions at } \\
\text { country level }\end{array}$ \\
\hline 2014 & $24 \%$ & $52 \%$ & $31 \%$ & $58 \%$ \\
\hline 2015 & $33 \%$ & $82 \%$ & $32 \%$ & $59 \%$ \\
\hline 2016 & $23 \%$ & $55 \%$ & $16 \%$ & $34 \%$ \\
\hline 2017 & $19 \%$ & $33 \%$ & $12 \%$ & $29 \%$ \\
\hline
\end{tabular}

Table 3 A Z-test comparison of performance for the period 2014-2017

\begin{tabular}{|c|l|l|}
\hline Year & \multicolumn{1}{|c|}{$\begin{array}{c}\text { Z-test for percentage mean } \\
\text { difference between Macheo } \\
\text { performance and country } \\
\text { performance for students who can } \\
\text { gain entry into university (p value) }\end{array}$} & $\begin{array}{c}\text { Z-test percentage difference } \\
\text { between Macheo performance and } \\
\text { country performance for students } \\
\text { who can gain entry into technical } \\
\text { institutions (p value) }\end{array}$ \\
\hline 2014 & 0.1275 & 0.015 \\
\hline 2015 & 0.975 & 0.557 \\
\hline 2016 & 0.567 & 0.409 \\
\hline 2017 & 0.618 & 0.776 \\
\hline
\end{tabular}

Gateways: International Journal of Community Research and Engagement, Vol. 12, No. 1,

February 2019 
U T S

e PRES S

The tables show that in the years 2014-2017, the absolute percentage of students transitioning from secondary to tertiary institutions was higher for the Macheo Mentoring Programme than country-wide figures, apart from its first year of operation in 2014. This is corroborated by a significant difference in the $\mathrm{p}$ value of 2014 (comparing students who gained entry into third-level institutions country-wide with those in the Macheo Mentoring Programme). It is important to note that there was a country-wide decline in performance in the years 2016-2017 because of a change in governance in the Ministry of Education which instituted new guidelines and a raft of changes, including how final examinations would be set and conducted.

\section{Possible factors influencing student success}

\section{STUDENTS' RESPONSES}

In terms of students' responses, mentorship aspects which affected students' academic success can be classified broadly into activities which happened before the actual mentorship (prementorship activities), activities which happened during mentorship (mentorship process activities), and activities which sustained students in the Macheo Mentoring Programme.

Students indicated that the pre-mentorship activities that related to students' success included: contacting prospective candidates to be mentored early on in the process (44 agreed on the importance of this, $\mathrm{p}=0.06$ ); explaining the objectives of Macheo from the start of the mentoring process, which influenced the types of skills students acquired (63 agreed on the importance of this, $\mathrm{p}=0.031$ ); explaining mentorship objectives, which linked to students proceeding into tertiary institutions (67 agreed, $\mathrm{p}=0.05)$; matching of mentor and mentee (66 agreed, $\mathrm{p}=0.024)$; and development of skills (69 agreed, $\mathrm{p}=0.05$ ).

Mentorship process activities associated with students' success in school exams included: the topics that a mentor discussed (63 agreed, $\mathrm{p}=0.041$ ), analysing students' performance (64 agreed, $\mathrm{p}=0.00$ ) and willingness of a student to continue in the Macheo Mentoring Programme. This encouraged a student to persevere with Macheo and would influence longterm involvement of the student (75 agreed, $\mathrm{p}=0.047$ ).

The aspects which sustained students in the Macheo Mentoring Programme and contributed to student success were: willingness of students to continue with Macheo (74 agreed, $\mathrm{p}=0.004$ ) and discussion with the mentor about challenges students experienced (34 agreed, $\mathrm{p}=0.019)$.

\section{PARENTS' RESPONSES}

Responses given by parents on what was likely to affect students' academic success from the perspective of mentoring can be divided into two broad factors, Macheo itself and the mentor's role. In terms of the former, 53 parents agreed that if their children continued with Macheo they would pass the Kenya Certificate of Secondary Exams [KCSE] ( $p=0.034)$ and would make it to a tertiary institution ( $\mathrm{p}=0.044) ; 52$ parents linked improved performance to attendance $(\mathrm{p}=0.036)$. The more parents were informed of Macheo Mentoring Programme activities, the more likely they thought their child would succeed $(\mathrm{p}=0.08)$.

Parents strongly agreed that, if they knew the mentor of their child $(\mathrm{p}=0.000)$, then their child would most likely succeed, and this would also enable them to receive regular updates 
about their child ( $\mathrm{p}=0.03$ ). Despite this, 37 mentioned that they did not know their child's mentor and consequently few received updates.

The responses above focus only on the significant relations - parents/guardians and students. There were other responses in the questionnaires which were not significant and not given too much focus in this research. It can be seen that the responses of students mainly focused on the Macheo Mentoring Programme itself and their direct involvement in the mentoring activities from induction to exit, while the responses of parents mainly focused on their perceptions of Macheo and not their direct involvement. However, parents and guardians can be directly involved if they have frequent contact with their child's mentors.

\section{OTHER CHALLENGES}

The research investigated other challenges that can directly or indirectly affect mentoring activities. Many parents (47) indicated that they lacked money to pay the school fees and hence were not involved in school fundraising activities. Engagement in fundraising activities needed extra time and sources of income from parents. A single mother said, 'I am a single mother of four and cannot adequately support my children'; another parent said, 'I'm sick and find it difficult to offer enough support to my child'. These extra funds from fundraising activities would have supplemented income schools receive from government and other sources and could lead to a reduction of school fees. The main reason for nonpayment of fees was lack of a constant source of income ( 25 parents). The reasons why some parents were not involved in fundraising activities at school was because of a lack of funds (7 parents), fundraising activities were not held in school (11 parents) and others did not have a concrete reason (56 parents). A parent expressed his inability to be involved in fundraising activities as follows: 'I earn low wages and therefore cannot participate in school's fundraising activities'.

A total of 44 students indicated that their parents lacked funds. The challenges students experienced varied from lack of basic needs, lack of funds, no attention in the family, sickly guardians, living far from school, few school materials, insults from relatives, family conflicts, poor housing and living conditions, and lack of support from relatives. Students thought that by being God fearing (10 students), conscientious hard workers (15 students) and having access to reading materials (6 students), they would succeed. Other challenges experienced at home that could indirectly affect mentoring success were expressed by one student when she said, 'I lack enough study time because of household chores'; others complained, 'I have noisy neighbours' or 'I lack fare and school fees'.

\section{Discussion}

\section{COMPLEMENTARY ROLE OF MENTORING PROGRAMS}

The Macheo Mentoring Programme was designed to complement, not supplement, teaching and learning activities in schools (Cochran-Smith 2003). This implies that school activities act as a foundation for activities undertaken in mentoring programs. For example, a mentoring program may supply reading materials that are not readily available in schools (Mullis et al.2012) or parents cannot provide; provide extra support teachers for these programs, especially if the children come from schools with high teacher-pupil ratios (Abuya \& Ngware 2016; Mugo 2012); and may create extra reading environments where students can interact. In the Macheo case, university lecture rooms or a community hall were used as

Gateways: International Journal of Community Research and Engagement, Vol. 12, No. 1. 
U T S

e PRES S

extra reading spaces on specific days. The complementary role points to having a stronger school-mentoring program connection in order to strengthen and support teachers' roles. In some cases, providing short, rapid response courses to respond to challenges in schools can lead to further success of mentoring programs. Mentors need to be known by parents/ guardians of mentees.

\section{EFFECT OF MENTORSHIP ACTIVITIES ON STUDENT SUCCESS}

Mentorship activities can lead to students' improvement in performance in specific subjects as well as overall performance (Turner, Meyer, Midgley \& Patrick 2003). Emphasis needs to be placed on specific subjects during mentorship where they have a strong relationship to other subjects. In the case of the Macheo Mentoring Programme, it was established that improvement in Mathematics would bring about an improvement in STEM subjects and overall academic success (NRC 2013; Shaban 2015). This implies that support teachers in mentoring programs should have a strong background and knowledge of STEM subjects, in particular.

\section{ENABLERS OF A MENTORING PROGRAM}

Certain features act as enablers in a mentoring program and help achieve positive outcomes. Such enablers include making parents or guardians co-participants in the mentoring process (Rhodes \& Dubois 2008) and breadth and depth of teaching and learning activities in schools (Moir \& Gless 2001). At the student level, a positive attitude, critical thinking and concern for others help improve subject and student performance (Dubois \& Silverthorn 2005; Murray 2001). These can be fostered by mentoring programs.

\section{QUALITY OF SUPPORT TEACHERS IN MENTORING PROGRAMS}

As mentioned above, the quality of support teachers has an impact on improvement in students' scores (Turner et al.2003). Quality support teachers need to work with mentors to guide students in specific subject areas. These teachers can provide further pointers to mentormentee-academic engagement, especially on how to help weak students. In order to attract good support teachers, funds need to be set aside to pay them. Good support teachers can provide specific subject advice to teachers in informal schools where student mentees come from and may be used to organise short teacher enhancement courses to address any skills that need to be acquired within a short time.

\section{EFFECT OF GOVERNMENT ON MENTORING PROGRAMS}

Government policies, structures and processes have an impact on schools' functions and consequently on the success of mentoring programs (Judd 2017). Radical changes made by government can either dampen or improve students' success. In the case of the Macheo Mentoring Programme, the strict changes in final year summative assessments made by the government's national examining body brought uncertainty about the knowledge to be evaluated in different subjects. This had a negative effect on the schools and the academic success of Macheo in the years when the radical changes were instituted. This implies a need for government to work together with schools, teachers and other stakeholders before instituting radical changes. 


\section{IMPACT OF SOCIOECONOMIC CHALLENGES ON MENTORING SUCCESS}

Since many students from informal settlements face many socioeconomic challenges, academic support should be coupled with life skills training. This will assist them to navigate life challenges they face in their situation. In addition, provision of materials not easily accessible in these schools will further improve students' success.

\section{Limitations}

A limitation of the study was the lack of pre-test and post-test comparisons of students' performance since the study focused only on students engaged in the Macheo Mentoring Programme and did not examine other students who were not, though country-wide score comparisons were made. The research would have benefited further from insights of other students in similar schools but not involved in Macheo. However, this would have proven somewhat difficult as it is not easy to go into schools to perform investigations without explicit permission from education officials. Other similar projects initiated by donors, together with country education officials, could make such comparisons. A deeper investigation into other aspects of students' success, for instance, possession of life skills, creation of a sense of responsibility and formation of a positive attitude towards learning, was not conducted. Examining possession of life skills and sense of responsibility needs more qualitative data of a longitudinal nature to highlight how such skills are being exercised by the students in society. Assessing positive attitudes towards learning requires involvement from principals and teachers in the various schools, which cannot be easily done for reasons mentioned earlier. Generalisability of these research findings is restricted to the outcomes of the Macheo initiative.

\section{Conclusions and recommendations}

The conclusion that can be drawn from this research is that there is a link between mentorship and students' success in the years under study (2014-2017). There is a need to compare the outcomes of this research with other mentoring initiatives in the Global South. Such comparisons should take note of the mentoring approach, background of the students and other socioeconomic conditions (Karcher et al. 2006). This research posits that, apart from service-based learning, which is important to ensure students are ready for the world of work, societal consciousness and student outcomes can be improved by incorporating mentorship programs such as Macheo into mainstream university activities. Universities, as with Strathmore University, can share with other universities in the Global South experiences and knowledge on how to better structure such programs within their own modes of operation.

The Macheo Mentoring Programme presented here is just one viable way to ensure improved academic and transition outcomes for underserved students. Importantly, it demonstrates that there is a need to involve tertiary institutions in developing policies friendly to community service initiatives, especially where radical education changes are involved. There are untapped knowledge resources in tertiary institutions that can support educationfor-all initiatives in developing countries. Many universities have networks with governmental, non-governmental and business organisations and have many students enrolled in their programs. These networks can be activated to respond to community challenges. Government can formulate policies that encourage businesses to coordinate with universities to resolve community challenges and, in return, receive tax reductions. Universities can assist government by creating a database of community challenges which universities can respond to, with 
U T S

e PRES S

funding support from governmental, non-governmental and business organisations. Students can receive credit for involvement in mentoring programs and businesses can incorporate this criterion in its advertised criteria for new employees. The Macheo Mentoring Programme has contributed to improvement in subject scores and average performance of high-school students. Furthermore, it has encouraged these high-school students in informal settlements to transit to tertiary institutions.

\section{Acknowledgements}

The manuscript was first submitted to Gaterways as part of its pilot Author+Editor mentoring program in late 2017. The author and Gateways journal would like to sincerely thank all those who contributed so generously to the article's development. These include: the three peer referees Dr Joan Kabaria-Muriithi, Kenyatta University, Dr Thoko Mnisi, University of KwaZulu-Natal, and Dr Patti Silbert, University of Cape Town; Prof Paul Ashton for his input on final drafts; and Margaret Malone for her mentoring. Dr Penny O'Donnell, University of Sydney, is especially thanked for her generous donation to UTS Shopfront at the Centre for Social Justice and Inclusion, which made the mentoring pilot possible.

\section{References}

AAI 2016, State of education in Africa report 2015: A report card on the progress, opportunities and challenges confronting the African education sector, The Africa-America Institute, New York.

Abuya, B \& Ngware, M 2016, 'Reflection of teachers in the FPE era: Evidence from six urban sites in Kenya', Sage Open, 12 February, pp. 18. https://doi.org/10.1177/2158244016629189

African Union 2006, African Youth Charter, African Union Commission, Banjul, Gambia, West Africa.

Allavida 2012, Access to and quality of basic education in Kibera, Uwezo, Kenya.

Beins, B \& McCarthy, M 2012, Research methods and statistics, Pearson, Boston, MA.

Bordens, K \& Abbott, B 2011, Research design and methods: A process approach, 8th edn, McGraw-Hill, New York.

Brockbank, A \& McGill, I 2006, Facilitating reflective learning through mentoring and coaching, Digital Publishing Solutions, London.

Burgess, R 1989, The ethics of educational research, The Falmer Press, New York.

Cochran-Smith, M 2003, 'Teaching quality matters', Journal of Teacher Education, vol. 54, no. 2, pp. 95-98. https://doi.org/10.1177/0022487102250283

Cohen, L, Manion, L \& Morrison, K, 2007, Research methods in education, 6th edn, Routledge, London.

COP 2013, The Macheo Mentoring Programme, Strathmore University, Nairobi, Kenya.

Cranwell-Ward, J, Bossons, P \& Gover, S 2004, Mentoring: A Henley Review of Best Practice, 1st edn, Palgrave Macmillan, New York. https://doi.org/10.1057/9780230509214

Creswell, J 2008, Research design: Qualitative, quantitative and mixed methods approaches, 3rd edn, SAGE, London.

Dennison, S 2000, A win-win peer mentoring and tutoring program collaborative model, The Journal of Preliminary Prevention, vol. 20, no. 3, pp. 161-74.

Dignitas 2008, Research report: Mathare Valley, Dignitas, Nairobi.

Gateways: International Journal of Community Research and Engagement, Vol. 12, No. 1,

February 2019 
Dubois, D \& Silverthorn, N 2005, 'Natural mentoring relationships and adolescent health', American Journal of Public Health, vol. 95, pp. 518-24. https://doi.org/10.2105/ajph.2003.031476

Dugan, J 2006, 'Involvement and leadership: A descriptive analysis of socially responsible leadership, Journal of College Student Development, vol. 47, no. 3, pp. 335-43. https://doi.org/10.1353/csd.2006.0028

E1 Bouhali, C \& Rwiza, G 2017, 'Post-millenium development goals in Sub-Saharan Africa: Reflections on education and development for all', in E Shizha \& N Makuvaza, eds, Re-thinking postcolonial education in Sub-Saharan Africa in the 21st Century: Post Millenium Development Goals, Sense Publishers, Rotterdam, pp. 15-32. https://doi.org/10.1007/978-94-6300-962-1_2

Furco, A 1996, 'Service learning: A balanced approach to experiential education', in Expanding boundaries: Service learning, Corporation for National Service, Washington, DC, pp. 2-5.

Glennerster, R, Kremer, M, Mbiti, I \& Takavarasha, K 2011, Access and quality in Higher Education System: A review of the progress, challenges and potential solutions, Office of the Prime Minister, Nairobi, Kenya.

Heiman, G 2011, Basic statistics for the behavioural sciences, 6th edn, Wadsworth Cengage Learning, Belmont, MA.

Higgins, M \& Kram, K 2001, 'Reconceptualizing mentoring at work: A developmental network perspective', Academy of Management Review, vol. 26, no. 2. https://doi.org/10.2307/259122

Jackson, Y 2002, Mentoring delinquent children: An outcome study with young adolescent children, Journal of Youth and Adolescence, vol. 31, no. 2, pp. 115-22. https://doi.org/10.1023/a:1014017909668

Jacobi, M 1991, 'Mentoring and undergraduate academic success: A literature review', Review of Educational Research, vol. 61, no. 4, pp. 505-32. https://doi.org/10.2307/1170575

Judd, M 2017, Impacts of mentoring programme on at-risk students, Murray State University, Murray KY.

Karcher, M, Claytie, D \& Powell, B 2002, 'The effects of developmental mentoring on connectedness and academic achievemen', School Community Journal, vol. 12, no. 2, pp. 35-50.

Karcher, M, Kuperminc, G, Portwood, S, Sipe, C, Taylor, A 2006, 'Mentoring programs: A framework to inform program development, research and evaluation', Journal of Community Psychology, vol. 34, no. 6, pp. 709-25. https://doi.org/10.1002/jcop.20125

Kathuri, J \& Juma, J 2007, Slum education: Making low income schools relevant, The Inter Region Economic Network (IREN), Nairobi, Kenya.

Keller, T 2007, 'Youth mentoring: Theoretical and methodological issues', in T Allen \& L Eby, eds, The Blackwell handbook of mentoring: A multiple perspectives approach, Blackwell Publishing, Malden, MA, pp. 23-43.

Moir, E \& Gless, J 2001, 'Quality induction: An investment in teachers', Teacher Education Quarterly, vol. 28, no. 1, pp. 109-14.

Mugo, J 2012, Access to and quality of basic education in Kibera, Nairobi, Allavida Kenya, Nairobi, Kenya.

Mullis, I, Martin, M, Foy, P \& Arora, A 2012, TIMSS 2011 International results in Mathematics, TIMSS and PIRLS International Study Centre, Chestnut Hill, MA.

Murray, M 2001, Beyond the myths and magic of mentoring: How to facilitate an effective mentoring process, Jossey-Bass, San Francisco, CA.
Gateways: International Journal of Community Research and Engagement, Vol. 12, No. 1,

February 2019 
U T S

e PRES S
Mutisya, E \& Yarime, M 2011, 'Understanding the grass root dynamics of slums in Nairobi: The dilemma of Kibera informal settlements', International Transaction Journal of Engineering, Management, Applied Sciences and Technologies, vol. 2, no. 2, pp. 197-213.

NRC 2013, The mathematical sciences in 2025, National Academies Press, Washington, DC.

Omenya, A \& Lubaale, G 2012, 'Understanding the tipping point of urban conflict: The case of Nairobi, Kenya', Urban Tipping Point Project, May.

Onsongo, D 2017, 'Leaders demand re-mark and probe into mass KCSE flop', Daily Nation, Nairobi, 22 December.

Punnett, J, Ford, D, Galperin, B \& Lituchy, T 2017, 'The Emic-Etic-Emic Research Cycle', AIB Insights, vol. 17, no. 1, pp. 3-6.

Rhodes, J 2002, Stand by me: The risks and rewards of mentoring today's youth, Harvard University Press, London.

Rhodes, J \& Dubois, D 2008, 'Mentoring relationships and programs for youth', Current Directions in Psychological Science, vol. 17, no. 4, pp. 254-58. https://doi.org/10.1111/j.1467-8721.2008.00585.x

Sais, S 2016, The Conversation, https://theconversation.com/are-kenyan-children-ready-for-the-leapfrom-pre-primary-to-primary-school-65584, viewed 19 July 2017.

Sava, A \& Orodho, J 2014, 'Socio-economic factors influencing pupils' access to education in informal settlements: A case of Kibera, Nairobi County, Kenya', International Journal of Education Research, vol. 2, no. 3 .

Schmidt, M, Marks, J \& Derrico, L 2004, 'What a difference mentoring makes: Service learning and engagement for college students', Mentoring and Tutoring: Partnership in Learning, vol. 12, no. 2, pp. 205-17. https://doi.org/10.1080/1361126042000239947

Shaban, O 2015, The relationship between mathematics grades and the academic performance of accounting students' department, The European Proceedings of Social and Behavioural Sciences. https://doi. org/10.15405/epsbs.2015.05.6

Spencer, R 2010, 'Working to make it work: The role of parents in the youth mentoring process, Journal of Community Psychology, vol. 39, no. 1, pp. 51-59. https://doi.org/10.1002/jcop.20416

Thomson, A, Smith-Tolkien, A, Bringle, R \& Naidoo, T 2008, Service learning and community engagement: A cross cultural perspective, International Society for Third Sector Research.

Turner, J, Meyer, D, Midgley, C \& Patrick, H 2003, 'Teacher discourse and sixth graders' reported affect and achievement behaviours in two high-mastery/high-performance Mathematics classrooms. The Elementary School Journal, vol. 103, no. 4, pp. 357-82. https://doi.org/10.1086/499731

UCT 2018, University of Cape Town SHAWCO, www.shawco.org, viewed 20 February 2018.

UIS 2018, United Nations Educational, Scientific and Cultural Organization, http://uis.unesco.org/en/ country/ke, viewed 20 November 2018

Williams, J, Krista, S \& Claire, E 2016, 'Community service and service-learning at large American public research universities', in M Tania \& S Krista, eds, Civic engagement and community service at research universities, Palgrave Macmillan, Minnesota, pp. 84-98. https://doi.org/10.1057/978-1-13755312-6_5
Gateways: International Journal of Community Research and Engagement, Vol. 12, No. 1,

February 2019 